
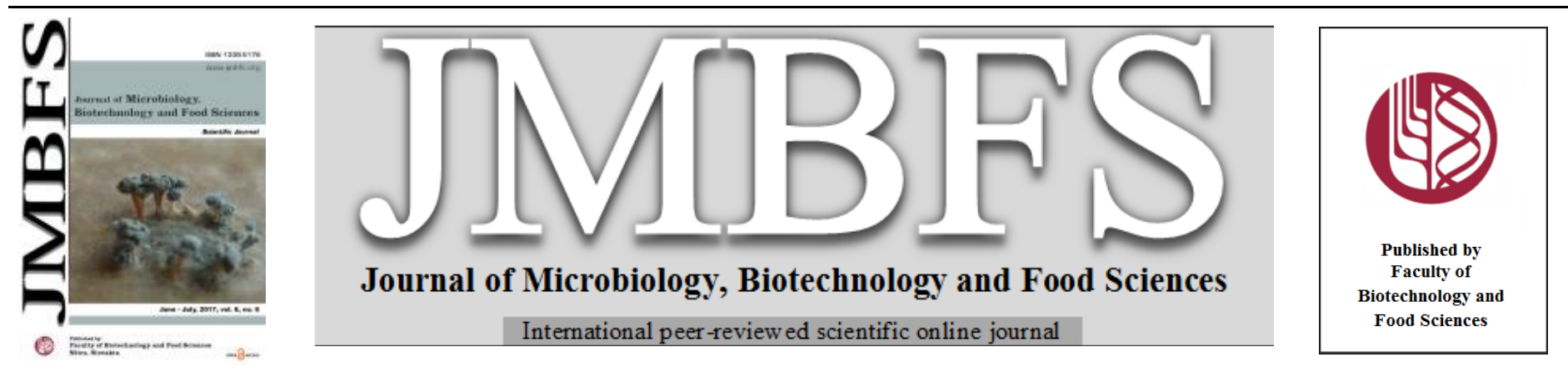

\title{
GENETIC DIVERSITY OF WINTER WHEAT (Triticum aestivum L.)
}

\section{Andrea Pešková*l, Zdenka Gálová, Tímea Kut'ka Hlozáková}

\author{
Address(es): Ing. Andrea Pešková, \\ ${ }^{1}$ Slovak University of Agriculture, Faculty of Biotechnology and Food Sciences, Department of Biochemistry and Biotechnology, Tr. A. Hlinku 2, 94976 Nitra, Slovak \\ Republic, phone number: +421376414693 .
}

*Corresponding author: peskova.andrea@gmail.com

doi: $\underline{10.15414 / j m b f s .2017 .6 .6 .1233-1236}$

\section{ARTICLE INFO}

Received 8. 3. 2017

Revised 10. 4. 2017

Accepted 2. 5. 2017

Published 1. 6. 2017

Regular article OPEN $\partial_{\text {ACCESS }}$

\begin{abstract}
Cereals form an indispensable part of the human diet, and wheat is one of the most important agricultural commodities worldwide. Technological quality of wheat grain is determined mainly by the representation of gluten proteins. The aim of this work was to evaluate the technological quality of winter wheat grain based on genetic markers rested on polymorphism of storage proteins. We analyzed ten varieties of winter wheat (Triticum aestivum L.), in which we determined the content of crude proteins and fractional composition of proteins. Then we analyzed the samples by electrophoretic methods using SDS - PAGE and A - PAGE protocols, which allowed us to separate storage proteins and subsequently to detect the presence of individual HMW-GS as molecular markers of breadmaking quality of wheat. We calculated Glu-score based on the representation of HMW-GS. According to SDS - PAGE, the most common composition of HMW-GS was formed by alleles $0,7+9,5+10$, which occurred in $30 \%$ of analyzed varieties (Natanael, Silvanus, Genoveva). The highest Glu-score (10) was achieved by the variety Ilias. From fingerprinting of gliadins in A - PAGE we constructed a dendrogram of relatedness of individual analyzed varieties. In dendrogram, most genetically distant varieties according to gliadins polymorphism are the varieties Silvanus from the varieties Bardotka, Sophytra, Faustina and Genoveva; also Natanael from the variety Sophytra. Genetically closest from this point of view is the variety Federer to the variety Panonnicus, as well as Natanael to Silvanus.
\end{abstract}

Keywords: winter wheat, technological quality, protein markers, HMW-GS

\section{INTRODUCTION}

Storage proteins of cereals are highly polymorphic. Their use in the form of suitable markers for the characterization and differentiation of genotypes have many advantages over other genetic markers (Žiarovská et al., 2012). Baking quality of wheat flour is largely determined by the accumulation, concentration and composition of proteins in the grain, which is influenced by genetic and environmental factors and their interaction (Malik et al., 2013). Grain consists of two main components, water and dry matter. Water is an important component, it is necessary for all biological and physiological processes. Dry matter is mostly represented by polysaccharides, about $75 \%$, the proportion of proteins is between 10-15 \% and content of lipids is about $2 \%$ (Kučerová, 2004). Endosperm is the main source of flour, it contains the largest amount of grain proteins, carbohydrates, iron and B vitamins (riboflavin, niacin and thiamine). Outer layers of the endosperm and the aleurone layer have higher concentration of vitamins and phytic acid, in contrast to the inner endosperm, where is the majority of starch and proteins (Kumar et al., 2011). Wheat storage proteins (gliadins and glutenins) with their properties differ from similar proteins in other cereals and that causes their exceptional position in cereal technologies. They are not soluble in water, but with the addition of water they swell to a limited extent, while insertion of mechanical energy by kneading in the presence of air form a solid gel, which is called gluten (Kadlec $\boldsymbol{e t}$ al., 2009). The quality of gluten plays a key role in shaping of the dough and also influences baking properties. Gluten proteins constitute in total about $80 \%$ of the protein content in wheat grain (Repka and Michalik, 1988). Gliadins, wheat prolamins, a major fraction of the wheat storage proteins, are synthesized in the endoplasmic reticulum during development of the seed. Gliadins are stored in subcellular structures within immature endosperm - in the protein bodies (Zhang, 2013). The structure of the gliadins consists of a single polypeptide chain, in which short helical sections ( $\alpha$ helix) alterante with hydrophobic residues and straight sections with relatively high content of glutamic acid and proline. Gliadins are classified into structural types: $\alpha-, \beta-, \gamma-, \omega$-gliadins according to their electrophoretic mobility in acidic systems (A - PAGE). Unlike glutenins, gliadins are the monomer components, which contribute to the viscosity of the particular dough expansion (Shewry and Halford, 2003; Kučerová, 2004). The glutenins, wheat glutelins, are divided into high molecular weight subunits (HMW-GS) and low molecular weight subunits (LMW-GS). They form about $40 \%$ of total proteins of grain, and are also among the largest molecules of the protein at all, achieved a molecular weight up to 20 milions Da (Wrigley, 1996). HMW-GS constitute of a stable complex of polymers and are linked mainly to the dough flexibility (Shewry and Halford, 2003). HMW-GS can be classified into the $\mathrm{x}$ - and y-type, which are coded by two genes and differ in molecular weight (Kolster, 1992). Bread wheat contains six HMW-GS genes, presented in each Glu-1A, Glu-1B and Glu-1D locus at the long arm of chromosomes 1A, 1B, and 1D (Shewry and Halford, 2003). Glu-score, calculated from presence of HMW-GS, is used to determine the breadmaking quality of wheat grain. The value of score is between 1 and 10 . The evaluation of wheat over 7 means good technological quality for bakery use. The amount of HMW-GS is not important for the breadmaking quality, but their individual representation. The most significant effect on the quality of the flour has locus Glu-1D, where the subunits $5+10$ affect the quality in a positive way and subunits $2+12$ in a negative way (Payne $\boldsymbol{e t}$ al., 1987). Study of protein polymorphism by electrophoretic methods is one of the most important ways to get information about varieties. The principle of protein markers allow us to determine the origin of cultivated plants and their genome structure, accurately and quickly identify the variety and specify their total genomic analysis (Gálová et al., 2011a).

\section{MATERIAL AND METHODS}

We analyzed grain of ten winter wheat (Triticum aestivum L.) varieties Bardotka, Sophytra, Lukullus, Federer, Pannonicus, Faustina, 
Genoveva, Ilias, Natanael and Silvanus, which were obtained from the Research and breeding station Malý Šariš NPPC VÚRV Piešt’any and the Breeding station HORDEUM spol. s. r.o. Sládkovičovo. We received grains from the growing season 2010/2011. We determined total nitrogen content by Kjeldahl's method and fractional composition of proteins by Golenko (Michalík, 2002), then we calculated crude proteins content (multiplying total nitrogen content with 5,7 which is coefficient for wheat) and coefficient of nutritional quality ((albumins + globulins + residue) $/$ prolamins $) \times 100$ ) from fractional composition of proteins. Storage proteins were isolated from the endosperm of dry and mature single grains. Homogenization was carried out by grinding. Glutenins and gliadins were extracted by standard ISTA method. Next we performed electrophoresis in acid conditions (Draper, 1987) and with presence of sodium dodecylsulphate (Wrigley, 1992) using the electrophoretic unit Protean II (BioRad). Protein bands were coloured by Coomassie Brilliant Blue $\mathrm{R}-250$. Electrophoretic profiles were scanned by GS-800 Calibrated Densitometer (BioRad), which cooperates with program Quantity One. The separated gluten subunits were identified by the protocol of Payne and Lawrence (1983). We evaluated the results by mathematical - statistical methods (average value, standard deviation and coefficient of variation). Dendrogram was constructed using Jaccard coefficient and the method UPGMA (Unweighted Pair - Group Method using Arithmetic Averages) in program, which is available free on http://usuaris.tinet.cat/debb/UPGMA/.

\section{RESULTS AND DISCUSSION}

Cereals are the most important plant source of proteins in the diet. The content and the quality of the individual protein fractions are the main factors, which affect the nutritional and technological quality of flour. On that basis, we determined total nitrogen content, content of crude proteins and also the fractional composition of proteins (Tab. 1). The content of nitrogen in the collection of analyzed varieties of winter wheat ranged from $1.40 \%$ in the variety Natanael to $2.30 \%$ in the variety Genoveva (average value was $1.73 \%$ ). We calculated the average value of crude proteins content at $9.88 \%$. The highest amount of crude proteins had the variety Genoveva (13.11\%) and the smallest the variety Natanael $(7.98 \%)$. Socha et al. (2010) determined the total nitrogen content of common wheat grains on $2.76 \%$, which is different from our results (about $1.03 \%$ ). The highest content of crude proteins was $15.75 \%$, which is about $2.64 \%$ more from our calculated value. Albumins and globulins are important fractions from a nutritional point of view, they contain more essential amino acids than prolamins and glutelins. For these protein fractions high content of lysine, threonine, methionine, isoleucine, tryptophan and arginine is typical. In turn, prolamines and glutelins have higher content of non-essential amino acids such as glutamic acid, proline and glycine. However, they are significant factor in development of gluten and they are irreplaceable during technological use of wheat in bakery. We found the highest content of albumins and globulins in the variety Natanael $(26.37 \%)$, the lowest content showed the variety Silvanus $(22.74 \%)$. The average rate was $24.55 \%$, which corresponds to the results of Gálová et al. (2011b), who determined the average value of $24.49 \%$, noting that the presence of albumins and globulins positively affects the nutritional value of wheat. Socha et al. (2010) found $22.62 \%$ fraction of albumins and globulins in wheat grain. This value is lower from our in about $1.93 \%$. Most prolamins were detected in the variety Faustina (39.82 \%), and least in the variety Ilias (28.56\%). Average value was $34.69 \%$. Silvanus variety showed the highest content of glutelins $(35.03 \%)$, the lowest value was detected in the variety Genoveva (28.04 $\%)$. Glutelins average content was $31.29 \%$.

\begin{tabular}{|c|c|c|c|c|c|}
\hline Variety & $\mathrm{CP}(\%)$ & alb + glo (\%) & prolamins (\%) & glutelins (\%) & CNQ (\%) \\
\hline Bardotka & 9,46 & 25,44 & 32,21 & 34,74 & 102,6 \\
\hline Sophytra & 9,69 & 24,16 & 35,95 & 30,05 & 94,57 \\
\hline Lukullus & 10,15 & 25,81 & 34,79 & 30,86 & 98,73 \\
\hline Federer & 9,58 & 24,36 & 34,46 & 28,52 & 107,42 \\
\hline Pannonicus & 10,55 & 25,92 & 35,64 & 30,24 & 95,73 \\
\hline Faustina & 8,89 & 23,76 & 39,82 & 31,47 & 72,09 \\
\hline Genoveva & 13,11 & 23,17 & 37,80 & 28,04 & 83,86 \\
\hline Ilias & 10,09 & 23,81 & 28,56 & 33,31 & 133,5 \\
\hline Natanael & 7,98 & 26,37 & 36,35 & 30,65 & 90,78 \\
\hline Silvanus & 9,29 & 22,74 & 31,35 & 35,03 & 107,24 \\
\hline average value (\%) & 9,88 & 24,55 & 34,69 & 31,29 & 98,65 \\
\hline standard deviation (\%) & 1,34 & 1,25 & 3,27 & 2,39 & 16,30 \\
\hline coefficient of variation (\%) & 13,59 & 5,10 & 9,42 & 7,64 & 16,53 \\
\hline
\end{tabular}

Legend: CP - crude proteins content, alb + glo - albumins and globulins, CNQ - coefficient of nutritional quality

Coefficient of nutritional quality indicates the quality of the grain in terms of its use for animal nutrition. From our varieties the highest value had the variety Ilias $(133.5 \%)$. This was also confirmed by its values of the sum and the ratio of gluten proteins, which are important from a technological point of view. Minimum nutritional quality was reflected by the variety Genoveva $(83.86 \%)$. All varieties showed average value of the coefficient of nutritional quality at the level of $98.65 \%$. These results are also approved by Gálová $\boldsymbol{e t ~ a l . ~ ( 2 0 1 1 b ) , ~ w h o ~}$ set the average value at $88.15 \%$. Difference between these values was $10.5 \%$, which means that our analyzed collection was on the higher level in regards to nutritional quality. Overall, we can conclude, that from our set of winter wheat, the most nutritionally valuable were varieties Ilias, Federer, Silvanus and Bardotka. From a technological point of view were the best varieties Faustina, Natanael, Bardotka and Silvanus. Žilič et al. (2011) analyzed the content of gliadins and glutenins in winter wheat genotypes and their content of these fractions were in the range of $58.17 \%$ to $65.27 \%$. Our average value was still higher, in about $0.71 \%(65.98 \%)$.

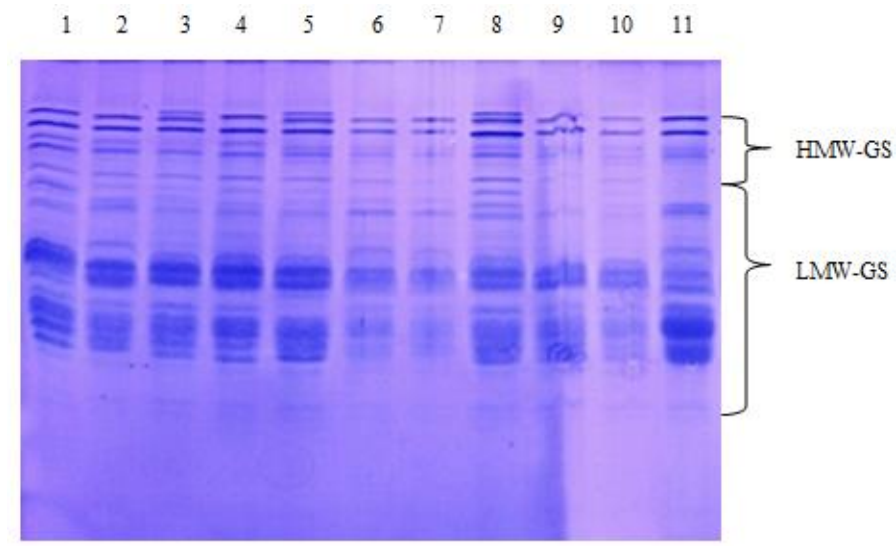

Figure 1 Electrophoretic profiles of storage proteins in grains of 10 winter wheat varieties using SDS - PAGE

Legend: 1 - Chinese Spring (marker), 2 - Bardotka, 3 - Sophytra, 4 - Federer, 5 - Lukullus, 6 - Natanael, 7 - Silvanus, 8 - Ilias, 9 - Pannonicus, 10 - Faustina, 11 - Genoveva, HMWGS - high molecular weight glutenin subunit, LMW-GS - low molecular weight glutenin subunits 
We used SDS - PAGE method to separate the storage proteins to HMW-GS and LMW-GS (Fig.1). Among analyzed varieties we detected the variability of presence HMW-GS and its influence to technological quality of grain. The most common HMW-GS composition (Fig. 2) in genetic resources was $0,7+9,5+10$ ( $30 \%$ varieties), the least common compositions were $0,7+8,2+12$ (Federer); $0,7+9,2+12$ (Pannonicus) and $1,7+8,10+5$ (Ilias).

Our results are consistent with Chňapek et al. (2014), who also found the most common composition of HMW-GS $0,7+9,5+10$. Our results suggested that from the genes, encoded by Glu-1A locus, most commonly occurred null allele (70 \% varieties), specifically in varieties Bardotka, Federer, Natanael, Silvanus, Pannonicus, Faustina and Genoveva, $30 \%$ varieties - Sophytra, Ilias and Lukullus contained subunit 1 . These results are confirmed by Kut'ka Hlozáková et al. (2015), who detected three alleles at the locus Glu-1A - 0, 1,2*. This was probably due to the size of their studied collection - 108 genotypes of winter wheat. Oslovičová et al. (2010) in their collection of 67 genotypes of wheat from Slovakia managed highest proportion of alleles 0 , which is consistent with our results. Locus Glu-1B was more common in the composition of HMW-GS $7+9$ (60\% - Sophytra, Lukullus, Nathanael, Silvanus, Pannonicus, Genoveva) as in the composition $7+8(40 \%-$ Bardotka, Federer, Ilias, Faustina). Kut'ka Hlozáková et al. (2015) at locus Glu-1B recorded high polymorphism, seven kinds of alleles, with the most frequent alleles $7+9$, which corresponds with our results. According to Oslovičová et al. (2010) at the locus Glu-1B occurred three kinds of alleles, namely $6+8,7+8$ and $7+9$. The most common pair was $7+9$, which is also consistent with our results. Composition $5+10$ prevailed at the locus Glu-1D (80 \% varieties - Bardotka, Sophytra, Lukullus, Nathanael, Silvanus, Ilias, Faustina, Genoveva), in contrast to $12+2$, which occurred only in $20 \%$ of varieties (Federer, Pannonicus). According to the results of Kut'ka Hlozáková et al. (2015), the presence of $5+10$ positively correlates with the breadmaking quality. Most often composition $5+10$ was also in the analysis of Oslovičová et al. (2010), however they detected subunits $2+12$ and $3+12$, too.
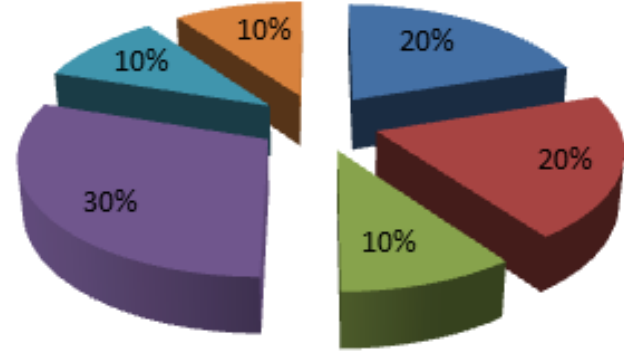

$0,7+8,5+10$

घ $0,7+9,5+10$

$0,7+9,2+12$

$\square 1,7+8,5+10$

Figure 2 HMW-GS component composition in analyzed collection of winter wheat

In the collection of our samples, we calculated Glu-score, which ranged from 5 to 10. Highest Glu-score 10 was reached by the variety Ilias, Glu-score 9 was found in the varieties Sophytra and Lukullus $(20 \%)$, varieties Bardotka and Faustina (20\%) reached the score of 8 , which means good technological quality of wheat grain. Still good Glu-score according to the criteria of Payne $\boldsymbol{e t}$ al. (1987), with a value of 7 , was reached by the varieties Natanael, Silvanus and Genoveva (30\%). The varieties Panonnicus and Federer do not comply with this classification, they reached a value of 5 and 6 . Average Glu-score was 7.6; which means satisfying technological quality of our collection of winter wheat. Chňapek et al. (2014) set in their collection of Czechoslovak and European wheat genotypes average Gluscore of 7.5; which agrees with our results. The largest percentage of their Gluscore was 9, while for us it was 7 .

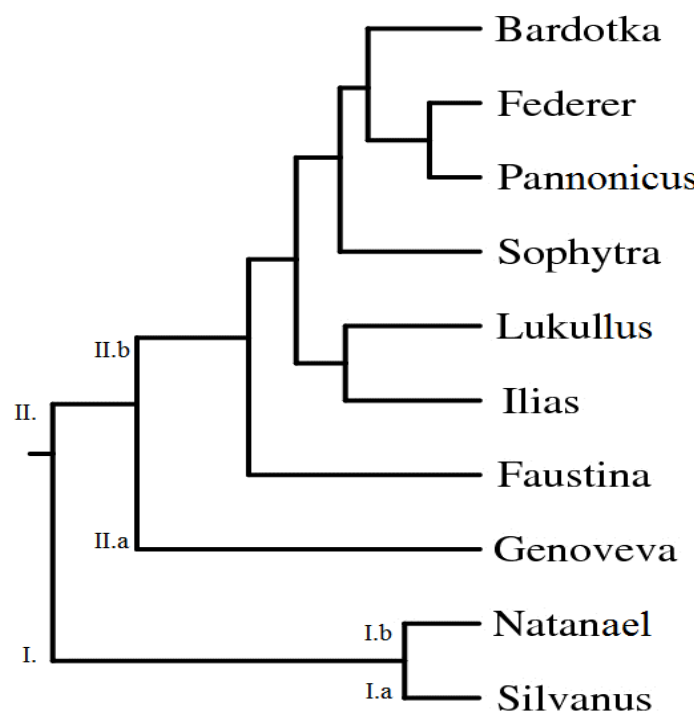

Figure 3 Dendrogram of genetic relatedness of varieties based on gliadins polymorphism

Electrophoretic analysis of gliadins from different wheat varieties received by A - PAGE method allowed us to use statistical methods in order to construct dendrogram of their relationships. On the basis of dendrogram (Fig. 3), common ancestors and degree of relatedness may be presumed. With variability analysis we divided the collection into two main clusters (I. and II.) of varieties. The first cluster (I.) contained only two varieties - Natanael and Silvanus (I.a and I.b), which indicate their close genetic relationship based on gliadins polymorphism. The second cluster (II.) was divided into two subclusters (II.a and II.b), the first (II.a) was characterized by the variety Genoveva, the second (II.b) was divided into two subgroups. The first subgroup was represented by the variety Faustina, the second was subdivided into two subclusters. The first subcluster contained the varieties Lukullus and Ilias, the second was separated into a group, which contained the variety Sophytra and the second group, which was next divided into clusters containing the varieties Federer and Pannonicus and cluster with the variety Bardotka. Genetic relatedness based on Jaccard similarity coefficient suggested, that gentically closest to the variety Federer is the variety Pannonicus $(0,889)$, followed by the varieties Natanael and Silvanus $(0,833)$ and a pair of the varieties Bardotka and Federer $(0,800)$. On the contrary, most genetically different varieties based on Jaccard coefficient were Bardotka, Silvanus, Sophytra and Faustina from Genoveva $(1,000)$, as well as Natanael from Sophytra (1,000).

\section{CONCLUSION}

Crude proteins content of the analyzed samples ranged from $7.89 \%$ to $13.11 \%$, the highest proteins content had the variety Genoveva and the lowest had the variety Natanael. The nutritional quality of wheat grain is based on representation of albumins and globulins, which content was between $22.74 \%$ in the variety Silvanus to $26.37 \%$ in the variety Natanael. Gliadins and glutenins content affects the technological quality of grain. The content of storage proteins varied between $61.87 \%$ in the variety Ilias to $71.29 \%$ in the variety Faustina. From this perspective, the variety Faustina had the highest quality according to content of gluten proteins. The highest ratio of coefficient of nutritional quality was detected in the variety Ilias $(133.5 \%)$, the lowest nutritional quality was reflected by the variety Genoveva (83.86\%). In terms of the representation of HMW-GS in the samples, we found subunits 0 and 1 at locus Glu-1A, subunits $7+8$ and $7+9$ at locus Glu-1B, and subunits $5+10$ and $2+12$ at the locus Glu-1D. Most frequently was component composition $0,7+9,5+10$, namely in the varieties Natanael, Silvanus and Genoveva. Glu-score can determine the technological quality of wheat grain. Our varieties reached Glu-score between 5 and 10. The highest score 10 was reached by the variety Ilias. The lowest rate had the 
varieties Pannonicus (Glu-score 5) and Federer (Glu-score 6). Based on the acidic electrophoretic profile of wheat storage proteins we constructed dendrogram of genetic relatedness of different varieties. In this regard, we determined that the variety Silvanus is genetically furthest from varieties Bardotka, Sophytra, Faustina and Genoveva, as well as the variety Natanael from variety Sophytra. On the other hand, the most genetically related were varieties Federer and Pannonicus. Finally, we can say, that the analyzed set of winter wheat showed a satisfactory technological quality and we recommend it for use in bakery.

Acknowledgments: This work was funded by European Community under project No. 26220220180: Building Research Centre "AgroBioTech" (50\%) and KEGA project No 021SPU-4/2015 (50\%).

\section{REFERENCES}

Draper, S. R. (1987). ISTA Variety Committee-Report of the working group for biochemical tests for cultivar identification 1983-1986. Seed science and technology (Switzerland).

Gálová, Z., Balážová, Ž., Michalík, I., Libantová, J., Moravčíková, J., Pret’ová, A., Matušíková, I. (2011a). Biotechnológie v rastlinnej produkcii. Nitra: SPU. ISBN 978-80-552-0682-0.

Gálová, Z., Trebichalský, A., Palenčárová, E. (2011b). Protein profil of Triticale (X Triticosecale Witt.), Wheat (Triticum aestivum L.) and Rye (Secale cereale). Potravinárstvo, 5(mimoriadne číslo február), 274-277.

Chňapek, M., Tomka, M., Peroutková, R., Gálová, Z. (2014). Polymorphism of HMW-GS in collection of wheat genotypes. International Journal of Biological, Biomolecular, Agricultural, Food and Biotechnological Engineering, 8(7), 652 657.

Kadlec, P., Melzoch, K., Voldřich, M. (2009). Co by jste méli vědět o výrobě potravin? Technologie potravin. Key Publishing: Ostrava. ISBN 978-80-7418051-4.

Kolster, P. (1992). High molecular weight glutenin subunits of wheat: qualitative and quantitative variation in relation to bread-making quality (Doctoral dissertation).

Kučerová, J. (2004). Technologie cereálií. Brno: Mendelova zemědělská a lesnická univerzita. ISBN 80-7157-811-8.

Kumar, P., Yadava, R. K., Gollen, B., Kumar, S., Verma, R. K., Yadav, S. (2011). Nutritional contents and medicinal properties of wheat: a review. Life Sci Med Res, 22, 1-10.

Kut'ka Hlozáková, T., Gregová, E., Gálová, Z. (2015). Genetic diversity of Glu-1 in European wheat genetic resources and varieties. The Journal of Microbiology, Biotechnology and Food Sciences, 4(2), $23-25$. https://doi.org/10.15414/jmbfs.2015.4.special2.23-25

Malik, A. H., Kuktaite, R., Johansson, E. (2013). Combined effect of genetic and environmental factors on the accumulation of proteins in the wheat grain and their relationship to bread-making quality. Journal of Cereal Science, 57(2), 170174. http://dx.doi.org/10.1016/j.jcs.2012.09.017

Michalík, I. (2002). Unifikovaná metóda diskontinuálnej frakcionácie bielkovinového komplexu zrna obilnín. Polnohospodárstvo, 48(7), 333-341.

Oslovičová, V., Gálová, Z., Chňapek, M., Balážová, Ž. (2010). Identification of Triticum aestivum L., Triticum spelta L.and Triticum durum DESF. genotypes on the HMW-GS base. Plant Soil Environ., 56(2), 82-86.

Payne, P. I., Lawrence, G. J. (1983). Catalogue of alleles for the complex loci, Glu-A1, Glu-B1 and Glu-D1 which code for high-molecular-weight subunits of glutenin in hexaploid wheat. Cereal Res. Commun., 11, 29-35.

Payne, P.I., Seekings, J. A., Worland, A. J., Jarvis, M. G., Holt, L. M. (1987). Allellic variation of glutenin subunits and gliadins and its effect on breadmaking quality in wheat: analysis of F5 progeny from „Chinese Spring“ x „Chinese Spring“ (Hope 1A). Journal of Cereal Science, 6(2), 103-118. http://dx.doi.org/10.1016/S0733-5210(87)80047-4

Repka, J., Michalík, I. (1988). Biochemicko - fyziologické základy šlachtenia rastlín. Nitra: VŠP - VES.

Shewry, P. R., Halford, N. G., Lafiandra, D. (2003). Genetics of wheat gluten proteins. Advances in genetics, 49, 111-184. http://dx.doi.org/10.1016/S00652660(03)01003-4

Socha, P., Raždíková, A., Urminská, D. (2010). Optimalizácia stanovenia celiakálne aktívnych bielkovín v cereáliách a pseudocereáliách. Potravinárstvo, 4(mimoriadne číslo február), 497-508.
Wrigley, C. W. (1992). Identification of cereal varieties by gel electrophoresis of the grain proteins. Seed Analysis. Berlin: Heilderberg, Springerverlag, $17-41$. http://dx.doi.org/10.1007/978-3-662-01639-8_2

Wrigley, C. (1996). Giant proteins with flour power. Nature, 381(6585), 738 739 .

Zhang, W., Sangtong, V., Peterson, J., Scott, M. P., \& Messing, J. (2013). Divergent properties of prolamins in wheat and maize. Planta, 237(6), 1465 1473. http://dx.doi.org/10.1007/s00425-013-1857-5

Žiarovská, J., Ražná, K., Senková, S., Štefúnová, V., Bežo, M. (2012). Variability of Linum usitatissimum L. based on molecular markers. ARPN Journal of Agricultural and Biological Science, 7(1), 50-58.

Žilić, S., Barać, M., Pešić, M., Dodig, D., Ignjatović-Micić, D. (2011). Characterization of proteins from grain of different bread and durum wheat genotypes. International journal of molecular sciences, 12(9), 5878-5894. http://dx.doi.org/10.3390/ijms12095878 